\title{
Colombia: The Link Between Drugs and TERROR
}

\section{Laura Garcés}

\section{INTRODUCTION}

The following paper focuses on the role played by drugs in the degradation of the Colombian conflict into terror. It begins with a brief review of the definitions of terror and proposes to view this phenomenon in its historical specificities. As a background to the analysis of the Colombian case, it also includes observations on the adulteration of conflicts in time through criminal collusion. The next section describes the origins of the Colombian conflict and the emergence of its main protagonists prior to the intervention of the drug factor. It then turns to the repercussions of this factor on the dynamics of the conflict.

\section{Terror and Terrorism: In Search of a Definition}

We introduce this piece by underscoring the inadequacies of the myriad definitions of terrorism. According to the lexicon of the U.S. State Department, terrorism consists of "premeditated, politically-motivated violence perpetrated against noncombatant targets by subnational groups or clandestine state agents, normally intended to influence an audience." By no means, however, does there exist a consensus on the proper acceptation of the term. Some observers focus on the nature of the perpetrator, distinguishing between individual, group, state, or state sponsored terrorism, while others concentrate on the process or its effects. Laqueur, one of the earliest U.S. scholars to have ventured on the subject, notes in his latest book that more than a hundred definitions have been offered without gaining widespread approval and that scholarship only agrees on the bare element

Laura Garcés is an independent scholar living in Washington, D.C. She is an ex officio member of the National Coalition of Independent Scholars' board and represents NCIS in the American Council of Learned Societies. She works on the cultural determinants of conflict. Presently, she is revising and updating an earlier book on the globalization of the Monroe Doctrine. 
that terrorism involves violence or the threat of violence - a rather discouraging introduction to his work. ${ }^{2}$

The plethora of definitions for terrorism underscores the deficiencies of a notion, which remains a political label rather than an analytical concept (Creenshaw, 1989). Policy makers have long held a monopoly on the subject, a fact that partially explains the oftentimes biased bent of the analyses offered. The very notion indeed squarely rests on the issue of legitimacy. Its discussion is therefore very much dependent on the values upheld by the observer. A Western understanding of the term, for instance, is completely at odds with Asian or Middle Eastern interpretations (Merabi, 1999). For example, the bombs dropped on Hiroshima and Nagasaki in 1945, touted by many in the West as weapons of victory, could be condemned as acts of terrorism. Islamic militants contend that Israeli occupation and intrusion into Palestinian territory represents terrorism, while Israel condemns suicide bombings and attacks in the same way. Discussions about terrorism, therefore, almost inevitably give rise to heated polemics/invectives that are hardly conducive to discussion.

The debate on Colombia is no exception. A society so polarized inevitably induces confrontations in which finger pointing overwhelms discussion. A common tendency, on the one hand, is to blame Colombia's elite and government for the terror inherent in the system's structure. This point of view maintains that generalized poverty has compelled certain groups to resort to terrorism in defense. This perspective generally also shows hostility to the imperialism of the United States and makes it the culprit of the drug trade, which would not exist without the demand in the North. This notion is shared by many among the country's establishment who resent Washington's accusations. They, however, also lament what they view as the congenital violent disposition of Colombians. They would welcome a U.S. intervention to restore order in this nation plagued by a strife the government cannot control. ${ }^{3}$

Contrary readings of the Colombian situation shrug off problems as the product of others and grossly simplify a predicament brought about by the convergence of various forces over time. However, inborn savagery is not a Colombian trait (Deas, 1997). Poverty explains neither drug production nor terrorism. ${ }^{4}$ And finally, the United States, far from being involved in an anti-Colombian-Andean conspiracy, contemplates potential involvement in this region very reluctantly. Nation building in an area very remote from its present concerns is hardly the predilection of the Bush administration.

How can one circumvent value-loaded assertions in a discussion of the subject? To avoid being trapped in dubious claims of legitimacy, terrorism can be understood as one form of coercion exercised against another. As Gurr explains, "coercion is a generalized set of means; repression is the consequence of their systematic application by the state; terrorism is dramatic, violent coercion used by any 
partisan group, in and out of power, to alter by shock and fear the state of mind of a target audience" (1986, p. 157). These various sources of coercion do not operate independently but are directly influenced by each other. Their interaction tends towards a balance. As Gurr writes, "The essential postulate offered here is that there is a general tendency toward equilibrium in the severity of coercion used by all groups contending for power within politically organized societies (...) To the extent that rebels do challenge highly coercive regimes, they will tend to rely on highly coercive tactics themselves, and vice versa" (p. 157).

The advantage of viewing terrorism in this "action-reaction" perspective is to remove the oft-held connotations of aberrant behavior, as well as the idea that there is one culprit in the terrorist dynamic. It follows from this that terrorism cannot be examined out of context. It is an endogenous process that proceeds from both international and domestic circumstances. In the case of long-term insurgencies, it can be crucial to understand in what way they have been affected by the passage of time and its events. Successes, frustrations, and failures have an important effect on the future of alternative movements. The development of terrorist ventures all over the world shows that frustration can produce hardening and intransigence among insurgencies. On the other hand, negotiations, even successful ones, often produce the splintering of coalitions. ${ }^{5}$ In analyzing the Colombian case, it is important to go back on the gestation and subsequent history of resistance. For over 40 years, the subject of intermittent peace negotiations with the government, the occasional offensives that it has endured and/or exerted, its interactions with other actors, have necessarily altered, sharpened, and/or adulterated its expectations and its programs.

The terrorist endeavor is therefore a process. To view terrorism as resistance should not lead us to infer that it is led by a purely rational mechanistic dynamic. It may start with clearly stated goals and adapt a strategy accordingly. Very often, however, strategies are adulterated. Goals, even, can change. "Terrorist experiences constitute processes during which their protagonists transform and renew themselves, while the intensity and the meaning of violence themselves evolve" (Wieviorka, 1995, p. 35). Shifts in position may be the result of successful or unsuccessful negotiations. The Palestinian, and Irish groups are two particularly telling examples because they have alternatively engaged in peace negotiations and broken out of these. Success, we have noted, can bring about a splintering of certain dissatisfied and hardened factions. The cohesion of terrorist groups, the members of which often live scattered and in hiding, is generally difficult to maintain.

So too is the integrity of their cause. The fate of negotiations is not the only factor determining their viability. Pragmatic economic issues are also a crucial factor. World Bank economist Paul Collier remarks, 
... what motivates conflict and what makes it feasible are two separate issues. In general, the existence of some form of grievance, whether economic, political, or social in nature, appears to be the most persuasive motivation for conflict. Greed, or more broadly, economic motivations - whether the pursuit of resources for war financing or for elite self-enrichment - appear more significant in sustaining, prolonging, and transforming conflict. (Woodrow Wilson International Center for Scholars, 2001, p. 1) ${ }^{6}$

The illegal nature of terrorist groups makes the collecting of funds uncertain, leading them to engage in sporadic alliances with groups that may not share their dissident views. Increasingly, terrorist movements across the globe are engaging in criminal activities. The terrorist-criminal nexus that was just emerging a decade ago is now a reality. Even before the end of the cold war, but increasingly since then, we have witnessed conflicts that have evolved beyond what triggered them initially, into a self-perpetuating dynamic. As Keen has argued in his insightful essay, "The Economic Functions of Violence in Civil Wars," protracted conflicts end up by generating their own parallel economy (Keen, 1998). Keen analyzes the economic benefits that violence serves by presenting a powerful obstacle to negotiation. He "suggests that internal conflicts have persisted not so much despite the intentions of rational people, as because of them. The apparent 'chaos' of civil war can be used to further local and short-term interests" (Keen, p. 11). His comparative approach to conflict in Africa, Latin America, Asia, and the Middle East shows persuasively that

...winning may not be desirable: the point of war may be precisely the legitimacy which it confers on actions that in peacetime might be punishable as crimes. Whereas analysts have tended to assume that war is the 'end' and abuse of civilians the 'means', it is important to consider the opposite possibility: that the end is to engage in abuse or crimes that bring immediate rewards, while the means is war and its perpetuation. (Keen, 1998, p. 12)

\section{What Are the Connections Between Organized Crime and Terrorism?}

In a few cases, links do exist between transnational criminal enterprises and terrorist organizations, although those links do not amount to a systematic organized crime-terrorism nexus. In some instances, organized crime uses terror tactics, more often, terrorist organizations use organized crime activities to fund their political 


\section{The Link Between Drugs and Terror}

and military campaigns. Each type of group, in effect, appropriates the strategies and tactics of the other when necessary or expedient. Yet this does not necessarily mean that there is a convergence of organized crime and terrorism. In many areas of the world, the distinctions between organized crime - which is essentially profit driven - and terrorism - which is about the pursuit of political change through the use of violence - remain clear and distinct. In other areas, however, such as parts of Africa, Central Asia, and the Balkans, and in specific countries such as Afghanistan, Burma, and Colombia, the traditional distinctions between politically motivated organizations and those seeking financial gain have become blurred amid a complex mixture of insurgency, factionalism, warlordism, terrorism, crime and corruption that is extremely difficult to disentangle, let alone manage. (Williams, 1996, p. 97)

This carries momentous implications, as we shall see in the specific case of Colombia. It necessarily entails a certain degree of compromise on the part of the insurgents. Its actual extent is a matter of conjecture. These alliances tend to be shifting and sporadic; they are bound by casual and tacit, rather than formal, commitments. Nonetheless, they open insurgencies to the prospect of lucre, and this carries at least two implications. In the case of old insurgencies, they present a high risk of dividing allegiances between an old guard, still keen about its principles, and younger generations more inclined to be swayed by the convenience of rapid material gain. More importantly, such transactions can betray professed political contentions.

The intersection of socio-political grievances and economics raises the issue of terrorist groups' depolitization, a question that needs to be pondered in the case of Colombia. Ideological concessions for the sake of needed funds can of course be justified on the grounds that they are compelled by revolutionary long-term goals. Nevertheless one can surmise that the terrorist groups' cohesion is compromised as a result. In respect to Colombia, diagnoses remain at odds. Despite the wellknown connections of the guerrillas with criminality, some analysts still perceive the guerrillas as motivated by unchanged ideological projects, while others consider that their revolutionary projects have now imploded. ${ }^{7}$

The collusion between the guerrillas and criminal actors introduces the question of the degradation of terrorism into terror. The boundary between terrorism and terror is unclear and probably tenuous. The issue, nevertheless, needs to be addressed because each of these reflects different stages in a society's breakdown. We understand terrorism here as a political strategy in pursuit of a goal. Even when its exercise 


\section{GARCÉS}

provokes widespread fear, it pursues clear goals. The intimidation caused among legal and judiciary personnel by the Colombian mafia in the mid 1980s was an obvious attempt to prevent extradition to the United States. Terror, as a system, is very different in that the fear exercised bears scant relation to any clear-cut goals. Unfortunately, the study of its dynamics has been mainly devoted to totalitarian systems, and little has been written on its manifestations in failed states. ${ }^{8}$ One can nevertheless posit that terrorism descends into terror when violent actions operate within a strategy, deliberate or not, that involves the civilian population against its will (Le Bot, 1994). What it manifests is a total loss of societal bonds and the dissolution of social and political collective identities. We will examine such gradual implosion in regard to the Colombian case.

The international factor, finally, must not be overlooked. ${ }^{9}$ We have noted one of its expressions, the emerging links between terrorism and transnational criminality, but there are other manifestations. As we have already posited, terrorism is a form of coercion exercised in response to and against other coercions, and the response of international actors should be taken into account in order to understand its general dynamic. In some cases and at some junctures, the weight of international protagonists may play a limited role. Today, however, there are at least four voices in this regards that must be taken into account: the United States; Europe (and/or relevant regional voices); the NGOs that have proliferated and have an increasing weight in international matters; and the existing international jurisdiction (e.g. criminal court) that, while not universally accepted, can have some influence in determining conduct. The response to these factors is important because they allow us to measure to what extent the issues at stake remain negotiable. When international pressure yields no apparent cooperative effect or appears to strengthen extremist obduracy, we are clearly confronting a situation in which terror has reached a selfgenerating dynamic. In the case of Colombia, we confront a mixed situation in which extremist factions (paramilitary vs. the guerrillas) have reacted to this factor in opposite ways. Increasing signs point nevertheless toward the active involvement of the International Community - its national as well as transnational actors. And while Colombia is not at present the focus of big power politics, an international influence is not to be discarded.

\section{Colombia in the $19^{\text {th }}$ and $20^{\text {th }}$ Centuries: Some Considerations on Its Formation, Structure and Dynamics}

This section discusses the formation of the Colombian political system and its coercive capacity and proposes to uncover some fault lines that compromised its solidity early on. We also explain how the political dynamic, as it developed, further weakened the state's control and eroded any potential nascent national identity. This 


\section{The Link Between Drugs and Terror}

discussion is important to understand the subsequent radicalization of politics. We will then turn to examine how these factors allowed for the emergence of alternative movements in the 1940s and 1950s, followed by the eruption of the drug factor beginning in the early 1970 s.

When pointing at the specifics of Colombian nation formation, two determining factors have to be underscored: geographical circumstances and a weak national identity substituted by strong party loyalties. Both of these elements conditioned the development of a state dominated by centrifugal tendencies.

Geography impaired the formation of a homogenous nation. Deeply fractured by the Andes, communities developed independent of each other. Regional allegiances overrode loyalty to the nation as an "abstract entity." ${ }^{10}$ Further, in contrast to Bolivia and Peru, the virtual extinction of indigenous cultures in Colombia operated as an obstacle to social identity. Geography also accounted for the slow development of domestic and international trade. Insufficient revenues from taxes and trade also explained the sparse presence of the state in many areas, some rendered remote by the prohibitive luxuriance that nature lent them. Colombia counted several mid-sized cities, which challenged central power in this financially strapped nation, while the capitals dominated in other Latin American nations.

The nation's intrinsic weakness was further compounded by socio-political factors. Instead of attempts at consolidation, the political dynamic as it developed early covered the narrow realm of elite interests. Partisans predated citizens (Sánchez, 1998, p. 35). The nation's heterogeneity suited the ruling elite that emerged in the first half of the 19th century within the economically privileged in two rival coalitions: liberals and conservatives. These were not polarized according to fundamentally different political, economic, and societal agendas. What differentiated them was their position on the influence of the church. The conservatives staunchly supported it and espoused centralism versus federalism. In the Cauca, where the conservatives staunchly resisted abolition, the issue of slavery debated in the mid $19^{\text {th }}$ century also opposed the two parties (Valencia-Llano, 1998, pp. 37-57). Liberals were also more associated with urban business, and the conservatives with the large landowners. Both feared the rise of a dictatorship and would shun the military in the $20^{\text {th }}$ century, contrasting with other nations in this part of the Southern Hemisphere. In time, the weakness of the military would naturally greatly hamper the government's coercive ability. But the largely illiterate masses hardly represented a threat, at least until the late $19^{\text {th }}$ century, as they were manipulated at will by each party's patrimonial Manichean rhetoric. True, given the physical absence of the state in many areas, expediency commanded that the masses seek the protection of the local boss, or "gamonal." And if nationalism was a poor vector of cohesion, party affiliations substituted, cutting across classes. This force was all the more polarizing since, in 
contrast to neighboring countries, Colombia was not involved in any prolonged outside war. Hence, energies were projected on partisan issues. Opponents were demonized and stigmatized as champions of anarchy and enemies of progress. ${ }^{11}$ The bloody conflicts that marred most of the $19^{\text {th }}$ century pitted conservatives against liberals. As Gonzalo Sanchez has observed, war in 19th century Colombia marked not the interruption, but the continuation of politics (1998).

Could a fierce struggle with a decisive outcome bring about a radical reevaluation of the political game? The civil war known as "La Violencia" (1948-1964), triggered by the murder of populist leader Jorge Eliécer Gaitán, showed the system strained to its breaking point. Yet it marked a parenthesis rather than a clear break in the country's history. In his study of the period, Daniel Pécaut writes,

..."La Violencia" begins with the will to maintain or reestablish
the political order, it proceeds with a combination of offensive and
defensive strategies, it concludes leaving an apparently unchanged
landscape, created from the same social structures, the same partisan
allegiances, the same precarious central state.... Everything goes on
as if nothing had happened ... communicating the feeling of a mere
interruption in the ordinary course of the oligarchic democracy.
Such is the conviction of the socio-economic elite.... (Pécaut,
1987, p. 338)

After a brief military interlude (promoted by the civil elite), a formula was devised whereby the two parties would alternate in power. While elections have now replaced this alternation, in reality the sharing of power persists to this day. The National Front, as it was dubbed, perpetuated the old order and neglected social issues. The exercise of power continued to be characteristically individualistic. Following a traditional pattern, many among the privileged classes resorted to private mercenaries to quell the unrest. Called "Pájaros" or "Chulavitas" according to the area they operated in, they murdered agents of sedition. This episode, however, was unsuccessful in eliminating foyers of resistance. The ongoing settlement also showed a strong individual component: Shortly after the beginning of La Violencia, between 1954 and 1964, "violence occurred through partisan and factional networks. But it operated by interfering with the supply of labor on coffee farms and with coffee and land markets. Since this was a means of redistribution and social ascent, we may call it "mafia violence"' (Safford \& Palacios, 2002, pp. 346-347).

The Colombian political system would continue to show its incapability of responding to organized movements of resistance. Movements of unrest would be more often co-opted, exploited, and reintegrated, mostly into the liberal party, rather 


\section{The Link Between Drugs and Terror}

than brutally suppressed. The failure to acknowledge political contentions and the tendency to seek compromise through the tacit traditional bipartisan arrangement set the Colombian system further and further apart from inclusion. In his analysis of party formation in Colombia, Solaún writes,

Colombia exemplifies the historical inability of a Third World twoparty system to evolve even as far as a representative government with limited participation or an inter-party competitive oligarchy. Attempts to go beyond protodemocracy by engaging in competitive inter-party electoral politics led to escalated violence, and so did full party dictatorship. (Solaún, 1980, p. 9)

The failure of Colombian governments to go beyond this tribal arrangement would have dire consequences on the peace overtures initiated in the mid 1980s during the Betancur presidency (1982-1986), which reached an impasse during the Andrés Pastrana administration (1998-2002) after alternating between conciliation and attempts at repression. Some question the existence of any thought-out plan:

...the first strategy ... is a feature of all recent Colombian
governments: none has developed or implemented a specific
strategy.... Other strategies include muddling through crisis
decision making, changing labels to counter various groups in a
policy vacuum, strategic dependence on one group of terrorists
to counter others, reactive strategies, the on-again, off-again
strategy of extradition, attempting to accommodate illegal practices
(prohibiting the payment of ransom), changing labels as a military
strategy, codependency on various groups, and negotiating
settlements. (Zarickson, 2002, p. 127)

In summary, the Colombian political system as it developed during the 19th century covered the narrow realm of bipartisan elite interests. Bipartisan competition and contentions became the regulating force of society. They largely substituted for national identity. They formed varied nuclei of power according to the area of their dominion, and they commanded loyalties. Individual expediency and the search for personal safety thus overrode the pursuit of collective goals. While ideological differences between these elite were unsubstantial, the struggle for state control gave rise to several harsh wars. At the time of La Violencia, there was no organized democratic alternative to this existing system. ${ }^{12}$ Moreover, the recourse to war was deeply embedded in the system. Far from eliciting a negotiating response 


\section{GARCÉS}

from the government, emerging alternative movements in the 1940s through the 1960s would result in the government's further restricting the political sphere. The National Front formed in 1957 after a brief military interlude established a formula whereby the two traditional parties would share power by alternating the presidency and dividing government positions. This "bipartisan monopoly aided by other authoritarian tools (permanent state of siege, autonomy of the military in the control of domestic order, and hyper-centralization of power vested in the executive) gave way to a restricted democracy" (Pizarro, 1989, p. 250). In time, the system produced patron-client relationships, establishing channels through which support was exchanged for various services. ${ }^{13}$ The international context of the cold war also shaped the government's obduracy. In short, it was "the lack of political and electoral democracy more than social and economic factors that generated the formation of armed movements" (Kalmanovitz, 2001, p. 19). This, then, is the background for the emergence of alternative movements. The agendas they proposed would prove just as rigid and impervious to change as the traditional system that fostered them. In addition, they also were permeated by individualism.

\section{Emergence of Alternative Movements}

The history of the guerrillas in Colombia antedates even the 1959 Cuban revolution. The subject has been well explored in recent years, and we limit ourselves here to singling out certain characteristics relevant to our discussion. There is no question that the domination of the state apparatus by the elite and the narrow space provided for alternative projects was favorable to the emergence of insurgent movements. Pockets of resistance had already formed in the 1920s and 1930s. They expressed mainly the peasantry's frustrations and demands, although urban unrest was also beginning to make itself felt. Shortly after La Violencia started, an agrarian and communist type of armed struggle also developed in Southern Tolima and in the Sumapaz Massif between 1954 and 1964, some of which may be considered direct antecedents of the guerrillero period (Safford \& Palacios, 2002, pp. 346-347).

The Fuerzas Armadas Revolucionarias de Colombia (FARC) were formally established in 1966. Their agenda reflected agrarian concerns. Roughly at the same time, the Ejercito de Liberación Nacional (ELN) had its first nuclei trained in Cuba. The Ejército Popular de Liberación (EPL), of Maoist leaning, also emerged. An indigenous movement, the Quintín Lame, later added its voice to the resistance. And the almost exclusively urban-based M-19, as an intellectual form of protest, was formed in 1973. ${ }^{14}$ These movements were disparate both in their composition and in their agendas. An attempt to integrate the various dissident groups was unsuccessful. The coordinating board that was formed - La Coordinadora Guerrillera Nacional Simón Bolívar - was unable to achieve unity. The main leftist groups showed a 


\section{The Link Between Drugs and Terror}

rigid adherence to their doctrinal tenets, and, if they sometimes tuned their rhetoric to communitarian concerns, it was only marginally or not at all that they adapted their program in consequence. ${ }^{15}$

Early on, these various movements showed a Manichean perspective that divided the world between themselves and enemies. Their doctrinal intransigence and inflexibility also reflected that of the political system. "Permanent violence developed into ... a real perversion. Although generated by distinct and antithetical factors, the dynamic of violence of the guerrilla and that of the state have ended up mimicking each other, and represent a dead end for the left ..." (R. Sánchez, 2001, p. 128). In addition, some guerrilla ventures meshed early with banditry and reflected the individualism that stamped the Colombian culture. On the agrarian frontier especially, where the state remained characteristically absent, a Hobbesian climate has since operated. There, guerrillas melded with counter-guerrillas, and each took in unemployed and/or semi-employed youths in search of opportunity (Palacios, 1995, p. 235). The lawless entrepreneur was perhaps born on the frontier and with him the value of little effort and quick rewards.

Just as the establishment had traditionally closed the way to compromise, the various leftist movements never entirely backed genuine negotiations. A long-time observer of the subject, political scientist Eduardo Pizarro deplores the FARC's refusal to put down its arms during negotiations. He attributes this in part to the largescale murder of the rank and file of the legitimate communist party, Union Patriótica, formed after the May 1984 cease-fire (Pizarro-Leongómez, 1991, p. 207).

Some movements, however, were successfully reintegrated into the system, such as the urban-based, more educated M-19 movement in 1990. In 1991, a peace agreement was signed with the EPL, the Partido Revolucionario de los Trabajadores (PRT), and the indigenous movement Quintín Lame. In 1994, a peace agreement was signed with the Corriente de Renovación Socialista (CRS).

However, many question the success of these reinsertions, since they did not open the system to a genuine alternative option. Some have stigmatized the M-19 because it virtually forsook its alternative agenda after opting for reinsertion (Bejarano, 1998, p. 152). But beyond discussing the specifics of each group's reinsertion into society, one can ponder and question the guerrillas' motivations in agreeing to peace negotiations. Historian Gonzalo Sánchez writes: "Doses of peace seem to equal programmed war. Partial negotiations, the Colombian experience seems to indicate, do not arrest the magnitude of the overall conflict, but simply serve as a space for the repositioning of the principal actors in the war" $(2001, \mathrm{p} .26)$.

In short, the various leftist movements that emerged between the 1920s and 1970s were unable through war and/or negotiations to provide the Colombian people with a realistic social and political agenda. Their adherence to rigid principles deprived 
them of a potential elevated number of partisans. In particular, this was the case of the ELN, which strictly adhered to the doctrine of the "foco," a doctrine first tested in the 1959 Cuban revolution and espoused by the Che and other advocates of Third World liberation. Inflexibility also impeded the meeting of these various dissident movements to discuss, agree on, and promote a common agenda. The demonization of enemies, characteristic of some revolutionist discourses, precluded any negotiation. Instead of the forging of a third way, therefore, dissident movements more often than not retracted towards the tacit acceptance of the system. The undeterred elements remained adamantly and defiantly reliant on a military solution. The dynamics of the system and of the armed opposition resulted "because of the mutual criminalization of the two conflicting poles" in sustaining "a vicious circle of 'retaliations vs. counter-retaliations' ... hindering the emergence of a genuine government-opposition design, that is to say of a pluralist democratic system" (Pizarro-Leongómez, 1991, p. 206).

Until 1985 through 1990, however, the guerrilla did not pose a real threat to the establishment. While it did generate a "chronic perturbation of the established order," its capability until that time was minimal (Bejarano, 1998, p. 152). This would change with the emergence of the drug factor.

\section{The Intrusion of Drugs Into the Colombian Conflict}

We have so far singled out some critical factors that facilitated the eruption of terrorism: a collective identity prone to individualism, an embryonic democratic system, and a traditional recourse to violence to settle conflicts. We discuss in the following pages both the quantitative and qualitative effects of drug trafficking on the Colombian conflict. We can distinguish two phases: the first that emerged in the late 1970s and lasted until the mid 1980s, during which time drugs played an instrumental role. In this phase, various mafia organizations resorted to terror as a tool for bargaining. Whenever these clans resorted to terror, it was to intimidate and often eliminate persecutors and to drive home to legislators, government officials, and the general public that they would violently resist any interference with their criminal activities. The question of extradition to the United States loomed high on their list of concerns. The second phase started in the mid 1990s and continues to this day. It is marked by the overwhelming of ends by means, the perpetuation and auto-reproduction of a violence that is no longer negotiable. This can be characterized as a system of terror, in which violence, erratic and random, replaces social and political regulation.

The growth of the illegal drug industry has been well detailed elsewhere, as have the reasons that propelled this phenomenon into Colombian society. Terrorism first began to be used as a tool to oppose and protest extradition to the United States after such a concession was elicited by Washington at the end of the 1970s. The 
mafia especially targeted the legal profession. Its actions resulted in a tremendous increase of threats and violence. In the $1980 \mathrm{~s}$, more than 220 judges were assassinated and more than 100 resigned. In addition, between 1985 and 1991, the number of homicides per year almost doubled, from about 15,700 to 28,280 . Peaks in this destructive momentum were reached in 1984 when Minister of Justice Rodrigo LaraBonilla was assassinated and again in August 1989 when liberal party presidential candidate Luis Carlos Galán was murdered. Public opinion, originally relatively detached on the issue of extradition, gradually opposed it, judging it too costly for Colombia. Polls conducted by the magazine Semana indicated that in December $1989,58 \%$ of Colombians were amenable to negotiating with the narco-traffickers, but in May 1991, roughly $82 \%$ of those polled favored a constitutional interdiction of extradition (Matthiesen, 2000). These opinions indicated a tolerance of illegality bordering on permissiveness. In addition and/or simultaneously to actual murder, some nuclei especially engaged in venality and sought to buy political and police protection. The extent of the mafia's penetration of the body politic became evident at the time of the presidential elections of 1994, when it was made known that President Samper's campaign had been significantly funded by drug lord contributions.

Drug barons did not limit themselves to combating extradition. Beginning in the late 1970s, they engaged in pragmatic ventures in their search for protection. Oftentimes these investors in extended latifundia hired the guerrillas to guard them. The latter were also "a ready source of protection for the industry's manufacturing and shipment operations in parts of the sparsely populated eastern half of the country that the guerrillas controlled" (Thoumi, 1995, p. 159). The funds generated by these new episodic alliances substantially increased the usual earnings generated by kidnappings, extortion, and various forced collections from the wealthy dubbed "fees." 16 As a result of the mafia-guerrilla collusion, the opposition that represented a marginal threat to the establishment until the 1980s soon became a direct challenge. Between 1991 and 1994, estimates showed an exponential increase in the number of guerrillas, from 7, 673 to 10,483 recruits and from 80 to 105 fronts (G. Sánchez, 2001). More significantly, beginning in the early 1990s, there was an incremental shift in the positioning of the guerrillas. They consolidated their gradual advance towards the more vibrant economic centers of the country. ${ }^{17}$ The insurgents' increased funding aggravated the paucity of the government's resources at a moment when it faced a particular need to fight the war on drugs (Thoumi, 1997).

The injection of drug money into the conflict not only altered the balance of forces in a financial aspect, it also entailed political consequences. By accepting to guard large latifundia for a fee, the guerrillas were directly countering their agenda for an agrarian reform (Pécaut, 1999). While they still claim their status as political 


\section{GARCÉS}

actors, expediency has commanded at least their short-term goals. For this reason, their actions have increasingly alienated public opinion.

The informal alliances contracted by the mafia with the guerrillas have entailed no solidarity. They followed a pragmatic pursuit of interests. Relations with the guerrillas were circumstantial and shifting. Cordial when elicited and driven by mutual interest, they could and did sour and snap on occasion. When the guerrillas kidnapped members of the mafia, they ignited a wrath that spurred and in fact assured the rapid increase of yet another substantial corroding force, the paramilitary. The narco-traffickers already resorted abundantly to the private enforcement of their interests through the hiring of killers known as "sicarios," targeting both government officials and leftist kidnappers. They were also instrumental in the development of the paramilitary.

Private armed militias have a long history in Colombia. Their existence is probably a corollary both of the state's weakness and of the simmering bipartisan conflict. They also hark back to the days of the Cold War and the fight against communism. They emerged in the fifties as individualized attempts to quell regional and local foci of unrest. Some members of the military, large landowners, and/or politicians welcomed, fostered, and financially assisted motley groups of guards and defense escorts, who came to be known under different appellations ("chulavitas," "pájaros," "guerrillas limpias," "guerrillas de paz" ... ) according to the area. ${ }^{18}$ Their existence was legally sanctioned in 1968, a decision eventually overturned in April 1989, when their collusion with some sections of the armed forces awoke criticism from Amnesty International and other human rights groups. ${ }^{19}$ They were revived, however, in 1994 during the Samper Administration under the somewhat euphemistic name of CONVIVIR, Cooperativas para la Vigilancia y la Seguridad Privada, which translates as Cooperatives for Vigilance and Private Security.

The organized Autodefensas Unidas de Colombia (AUC) emerged in 1981 under the leadership of Fidel Castaño, whose father had been murdered by the guerrillas two years before. After Fidel was assassinated, his brother Carlos took on its leadership and established its nucleus in Córdoba and Urabá. ${ }^{20}$ Like their foes the guerrillas, the AUC benefited abundantly from drug money. Illegal funds were even used for their training by Israeli instructors. And like the guerrillas, they also relied for their financing on fees charged for protection. The paramilitary consolidated themselves considerably in the 1980s and 1990s and are said today to count about 10,000 men. They generalized the practice of mass killings, seeking to eliminate peasants even when only vaguely suspected of colluding with the guerrillas. They mimicked the guerrillas in their carefully led insurrectional war, establishing local fronts to cleanse them from rebel-guerrilla presence. 


\section{The Link Between Drugs and Terror}

The injection of the drug factor introduced criminal pragmatism, an element that marked a fundamental turning point in the ongoing conflict. Its immediate repercussion was to corrode the political and, in particular, the judicial system. Deficient social capital, scant internalized ethical norms, and the characteristically individualistic disposition of Colombians offered a vulnerable terrain. The lack of consistent enforcement of the law nevertheless provoked "confusion between legality and illegality unknown before" (Pécaut, 2000, p. 2). Large-scale displacement of the peasantry induced by violence in the areas of confrontation brought about drastic alteration of society. "The narco-traffic caused a savage transformation of society, a violent secularization in respect to values, to social hierarchies, to the distribution of property, to the type of development, to the formation of a population of uprooted settlers, to the occupation of lands formerly peripheral" (Pécaut, p. 2). This reshifting of geography and populations has brought about a blending of different types of violence, including a purely criminal element that defeats any attempts at categorization.

The various types and manifestations of violence interact. One of the salient aspects of criminality in Colombia today is the prevalence of common crimes. This is at odds with other countries like The Basque Country or South Africa, where the height of political terrorism was characterized by sparse common crime. ${ }^{21}$ Jaramillo and Guerrero-Apráez (1997) note that $90 \%$ of homicides are not linked to politics. Rubio (1999) demonstrates on the contrary that the most violent areas of the country are also those where the armed protagonists are present.

Since the 1980s, violence in Colombia has assumed a multifaceted character, which is not reducible to factors of poverty, material backwardness, or weak presence of the state, although all of these have played a role (Rubio, 1999). As the 1988 Commission of Studies on Violence remarked in relation to urban violence,

[it] is multifaceted and two-sided: It involves sectors of economic, political and cultural life: the urban culture of violence is a synthesis of these facets, so it would be simplistic to reduce it to one of them. At the same time, it originates both from extremes of poverty and from forms of obtaining and protecting wealth, from rebellion as well as from domination; from intolerance as well as from the search for recognition.... (Comisión de Estudios sobre la Violencia, 1989, p. 9)

This signifies, if not disintegration, at least significant erosion of the political system, the autonomy of which is seriously compromised. Because the protagonists in the conflict "have acquired the potential to control the key economic and 


\section{GARCÉS}

productive sectors of the national economy," the "boundaries between political and nonpolitical violence, organized and unorganized crime are becoming more and more porous" (Pécaut, 1999, p 143).

Pécaut underscores the blurring in the distinction between types of violence:

There is still a difference between organized and random violence, but the two forms of violence have entered into a reciprocal relationship that has resulted in a situation of generalized violence. This generalized violence affects social and interpersonal relations, changing the workings both of institutions and of established values... The interaction between various forms of violence creates its own logic, its own modes of conflict, and systems of transaction. This violence is not based on class divisions or other collective forms of social identity. (Pécaut, 1999, p. 145)

The deleterious implications of these developments on the system of collective beliefs and hence on behavior have been underscored by a 1996 Inter-American Development Bank study by Luis Ratinoff:

No one trusts the viability of public protection any more, and the majority tends to believe that the only option is to reduce expectancies and to assume the risks privately. To survive, it is necessary to adjust to the peril of a situation that cannot be modified. These perceptions erode the fabric of public trust, provide incentive for defensive behaviors and auto-imposed restrictions to personal freedom and sow doubts on the nature of the existing social bond. (quoted by Jaramillo \& Guerrero-Apráez, 1997, p. 8)

\section{ConcLusion}

In the preceding pages, we have explained in what way the Colombian system showed itself vulnerable to terrorism. A chief contributing factor was the inexistence of an inclusive and open political system to orchestrate political demands and implement mechanisms of conflict resolution. The resulting individualistic methods had fundamental implications for Colombian politics and culture as a whole because they generated a society devoid of common pursuits. In the 1970s, the search for lucre through the illegal drug business compounded and further adulterated societal ties. It contaminated in particular the methods and goals of the armed protagonists and widely corrupted the government. Colombia became known, like Afghanistan, 


\section{The Link Between Drugs and Terror}

Pakistan and Burma, as a model of vicious transnational forces that will presumably extend itself in this century.

However, two new factors allow us to contemplate possible outcomes besides a fatal implosion. Both involve the mobilization of public opinion against the Colombian conflict. Public opposition to the war within the country and widespread resentment against the government's corruption have generated a mobilization of civic organizations and the creation of new associations intent on bringing an end to the conflict. In a country where lack of public participation is traditional, this development is promising and could indicate the gradual opening of the political system. The international factor must also be taken into account. Since President Pastrana's lobbying efforts brought Colombia to international attention (1998-2002), the growing voice of NGOs has been at times instrumental in forcing an increased respect of human rights issues. And while dominant voices in Washington continue to endorse a punitive approach, pushing, for instance in favor of the forceful spraying of illegal drugs, other nations, especially in the EU, support long-term strategies that work towards the rehabilitation and consolidation of the body politic. The intricate Colombian conflict has a long history, and time will be necessary to resolve it. However, signs do exist that the nation's future is by no means doomed.

\section{NOTES}

1 Quoted by Reich, 2002, p. 517. For the various official definitions of the term, see Hoffman, 2002, pp. 3-24.

2 Laqueur, 1999, pp. 5-6. Pillar, 2001, p. 12 speaks of a "semantic quagmire."

3 Contending interpretations of violence in Colombia are ably presented in Montenegro and Posada, 2001, pp. 27-44.

4 For an exhaustive discussion of the factors conducive to drug production, see Thoumi (2003). On a related subject, some criminologists have also argued that the existence of a weak state is not a causal factor in the development of criminal activity. It is a "necessary ... (but) not a sufficient condition" (Williams, 2001, p. 100).

5 See the discussion in this regard in Darby (2001, pp. 46-50).

6 An interesting discussion of Collier's views can be found in de Soysa, 2000, pp. $114 \mathrm{ff}$.

7 For a clausewitzean reading of the Colombian conflict, which implies that the guerrillas are driven by a rational behavior, see Rangel (2001). Other readings emphasize the degradation of the guerrillas' endeavor (Pizarro-Leongómez, 1996). Other perspectives propose an intermediate position that supposes on the one hand the continuity of political goals but underscore their adulteration through time. See Pécaut (2001). 
8 For a discussion on the paucity of our knowledge on the subject of violence and the state today, see Mazower, (2002, pp. 1158-1178). Mazower ascribes this theoretical void to "the very partial and Euro-centric version that still dominates the agenda in contemporary history of what counted in the century that has just passed" (p. 1178).

$9 \quad$ It has been noted that terrorism represents a resistance to the predominant forces that shape the international political environment. This comes out clearly in the changing content of terrorism these past 30 years. During the cold war, the homogenizing thrust of each bloc generated centrifugal movements in its midst that sought ideological alternatives. Today, expressions of terrorism are pushes of (ethnic, religious, nationalist) fragmentation aimed at resisting uniformity and globalization. In this respect, Colombia's communist movements present an unusual anachronistic case, a fact that underscores its autochthonous, insular character. On the changing content of terrorism through time, see Laqueur, 1996, pp. 24-36.

10 As noted by Bushnell, 1993, p. 74. See following pages for a discussion of geographical factors.

11 For insight into the rhetorical war of both parties, see Acevedo-Carmona, 1995, pp. 33-57.

12 Pizarro (1989, p. 257) remarks on the heavy cost that Colombian society had to suffer because of the absence of a democratic leftist alternative.

13 Leal-Buitrago (1990) dates the origin of clientelism to the beginning of the National Front in 1958 (p. 37) and underscores its eroding effect: "the ethical and moral transgression, the loss of social values, materialism ... and corruption" (p. 36).

14 For a chronology of these movements, see R. Sánchez, 2001, pp. 124-126.

15 For a discussion on the grievances endured by the indigenous communities on account of the various guerrillas, see Le Bot, 1994, pp.135-148.

16 G. Sánchez (2001, p. 24) quotes estimates indicating that the FARC derives roughly $50 \%$ of its funds from drug trade. Its second largest revenue is accrued from kidnappings. As for the ELN, it receives its main funding through extortions from oil companies and kidnappings, while drug monies ranks third at 20\%.

17 For detailed sketches and an exhaustive discussion, see Echandía-Castilla, 1999, pp. $45 \mathrm{ff}$.

18 This feature must be noted although scholars on the subject underscore the nonexistence of an organic link between these private groups and today's organized Autodefensas Unidas de Colombia (AUC). See F. Cubides (2000, p. $62)$. 


\section{The Link Between Drugs and Terror}

19 This is well discussed in Kline (1999, pp. 74-76).

20 An account of the AUC's history is given by Carlos Castaño himself; see Aranguren-Molina, 2001. A summary of salient points can be found in Guillermoprieto, 2002, pp. 23-25.

21 Darby (2001, p. 62) cautions us however not to draw rash conclusions from this, since other elements can intervene to lower the common crime statistics (poor records, harsh policing by paramilitary groups, etc.).

\section{References}

Acevedo-Carmona, D.

1995 La mentalidad de las élites sobre la violencia en Colombia (1936-1949). Bogotá, El Áncora Editores.

Aranguren-Molina, M.

2001 Mi confesión: Carlos Castaño revela sus secretos. Bogotá, Oveja Negra. Bejarano, J. A.

1998 Para que el derecho sea eficaz, el estado tiene que ser eficaz. In Entrevistas de Guillermo Solarte-Lindo (Ed.), No ha pasado nada, Una mirada a la Guerra. Bogotá: Tercer Mundo Editores.

Bushnell, D.

1993 The making of modern Colombia. A nation in spite of itself. Berkeley: University of California Press.

Comisión de Estudios sobre la Violencia

1989 Colombia: Violencia y democracia, Bogotá: Universidad Nacional de Colombia- COLCIENCIAS.

Creenshaw, $\mathrm{M}$.

1989 Terrorism and international cooperation. New York: Institute for East-West Security Studies.

Cubides, F.

2000 Flujos y reflujos del paramilitarismo. In Síntesis 2000. Anuario social, Darby, J. político y económico de Colombia. Bogotá: Tercer Mundo Editores.

2001 The effects of violence on peace processes. Washington, D.C. United States Institute of Peace Press.

Deas, M.

1997 Violent exchanges: Reflections on political violence in Colombia. In D. E. Apter(Ed.), The legitimization of violence. New York: New York University Press. 


\section{GARCÉS}

de Soysa, I.

2000 The recourse curse: Are civil wars driven by rapacity or paucity? In M. Bernal \& D. M. Malone (Eds.), Greed and grievance. Economic agendas in civil wars. Boulder: Lynne Rienner Publishers.

Echandía-Castilla, C.

1999 El conflicto armado y las manifestaciones de violencia en las regiones de Colombia. Bogotá: Presidencia de la República de Colombia, Oficina del Alto Comisionado para la Paz, Observatorio de Violencia.

Guillermoprieto, A.

2002 Confessions of a killer. The New York Review of Books, Vol. XLIX, No. 15, October 10.

Gurr, T. R.

1986 Persisting patterns of repression and rebellion: Foundations for a general theory of political coercion. In M. P. Karns (Ed.), Persistent patterns and emergent structures in a waning century. New York: Praeger.

Hoffman, B.

2002 Defining terrorism. In R. D. Howard \& R. L. Sawyer (Eds.), Terrorism and counterterrorism. Understanding the New Security Environment, Guilford, McGraw-Hill/Dushkin.

Jaramillo, J. C., \& Guerrero-Apráez, V.

1997 Conviviencia y violencia. Elementos para fortalecer la conviviencia ciudadana y disminuir la violencia. Final report to the Ministerio de Hacienda, Bogotá, July.

Kalmanovitz, S.

2001 Las instituciones colombianas en el siglo XX, Bogotá: Alfaomega.

Keen, D.

1998 The economic functions of violence in civil wars. London: Oxford University Press.

Kline, H. F.

1999 State building and conflict resolution in Colombia, 1986-1994. Tuscaloosa: The University of Alabama Press.

Laqueur, W.

1996 Postmodern terrorism. Foreign Affairs, September/October.

Laqueur, W.

1999 The new terrorism. Fanaticism and the arms of mass destruction. New York, Oxford:

Leal-Buitrago, F.

1990 Clientelismo. El sistema politico y su expresión regional. Bogotá: Tercer Mundo Editores. 
Le Bot, Y.

1994 Violence de la modernité en Amérique latine. Indianité, société et pouvoir, Paris Editions Karthala.

Matthiesen, T.

2000 El arte politico de conciliar. El tema de las drogas en las relaciones entre Colombia y Estados Unidos, 1986-1994. Bogotá: FESCOL, CEREC, FEDESARROLLO.

Mazower, M.

2002 Violence and the state in the twentieth century. American Historical Review, 107(4), 1158-1178.

Merabi, A.

1999 Du terrorisme comme stratégie d'insurrection. In Gérard Chaliand (Dir de), Les stratégies du terrorisme. Paris: Desclée de Brouwer.

Montenegro, A, \& Posada, C.E.

2001 La violencia en Colombia. Alfaomega.

Palacios, M.

1995 Entre la legitimadad y la violencia. Colombia 1875-1994. Bogotá: Editorial Norma.

Pécaut, D.

1987 L'ordre et la violence. Evolution socio-politique de la Colombie entre 1930 et 1953. Paris: Editions de l'Ecole des Hautes Etudes en Sciences Sociales.

Pécaut, D.

1999 From the banality of violence to real terror: The case of Colombia. In K. Koonings \& D. Kruijt (Eds.), Societies of fear. The legacy of civil war, violence and terror in Latin America. London: Zed Books.

Pécaut, D.

2000 Hilos de la madeja. El Tiempo, July 2, p. 2.

Pécaut, D.

2001 Guerra contra la sociedad. Bogotá: Editorial Planeta.

Pillar, P. R.

2001 Terrorism and U.S. foreign policy. Washington, D.C.: Brookings Institution Press.

Pizarro, E.

1989 La guerrilla y el proceso de paz. In G. Gallón-Giraldo (Ed.), Entre movimientos y caudillos. 50 años de bipartidismo, izquierda y alternativas populares en Colombia. Bogotá: CINEP. 


\section{GARCÉS}

Pizarro-Leongómez, E.

1991 Las FARC. De la autodefense a la combinación de todas las formas de lucha, 1949-1966. Bogotá: Tercer Mundo Editores.

Pizarro-Leongómez, E.,

1996 Insurgencia sin revolución. La guerrilla en Colombia en una perspective comparada. Bogotá, Tercer Mundo editores.

Rangel, A.

2001 Guerra insurgente. Conflictos en Malasia, Perú, Filipinas, El Salvador y Colombia. Bogotá: Intermedio.

Reich, W.

2002 Understanding terrorist behavior. In I. Cronin (Ed.), Confronting fear. A history of terrorism. New York: Thunder's Mouth Press.

Rubio, M.

1999 Crimen e impunidad. Precisiones sobre la violencia. Bogotá: Tercer Mundo Editores.

Safford, F., \& Palacios, M.

2002 Colombia. Fragmented land, divided society. New York: Oxford University Press.

Sánchez, G.

1997 Violencias, contrainsurgencia y sociedad civil en la Colombia contemporanea. Retrieved November 24, 2004, from www.Colombia-thema.org.

Sánchez, G.

1998 Guerre et politique en Colombie. Paris: 1'Harmattan.

Sánchez, G.

2001 Introduction. Problems, prospects for peace. In C. Bergquist, R. Peñaranda, \& G. Sánchez (Eds.), Violence in Colombia, 1990-2000. Waging war and negotiating peace. Wilmington: Scholarly Resources Inc.

Sánchez, R.

2001 Crítica y alternativa. Las Izquierdas en Colombia, Bogotá: Editorial La Rosa Roja.

Solaún, M.

1980 Colombian politics: Historical characteristics and problems. In R. A. Berry, R. G. Hellman, \& M. Solaún (Eds.), Politics of compromise. Coalition government in Colombia. New Brunswick: Transaction Books.

Thoumi, F. E.

1995 Political economy and illegal drugs in Colombia. Boulder: Lynne Rienner Publishers. 
Thoumi, F. E.

1997 Introducción y panorama. In F. E. Thoumi (Ed.), Drogas ilícitas en Colombia. Su impacto económico, político y social. Bogotá: Planeta Ariel Editorial.

Thoumi, F.E.

2003 Illegal drugs, economy and society in the Andes. Washington, D. C.: The Johns Hopkins University and the Woodrow Wilson Center for International Scholars.

Valencia-Llano, A.

1998 La guerra de 1851 en el Cauca. In Las guerras civiles desde 1830 y su proyección en el siglo XX. Bogotá: Memorias de la II Cátedra annual de historia Ernesto Restrepo Tirado.

Wieviorka, M.

1995 Face au terrorisme. Paris: Editions Liana Levi.

Williams, P.

2001 Transnational criminal enterprises, conflict and instability. In C. A. Crocker, F. O. Hampson, \& P. Aall (Eds.), Turbulent peace. The challenges of managing international conflict. Washington, D.C.: The United States Institute of Peace Press.

Woodrow Wilson International Center for Scholars

2001 The economics of war. The intersection of need, creed and greed, a conference report. Washington, D.C.: Woodrow Wilson International Center for Scholars.

Zarickson, J.

2002 Colombia. In Y. Alexander (Ed.), Combatting terrorism. Strategies of ten countries. Ann Arbor: University of Michigan Press. 


\section{GaRcÉS}

